\title{
THE INTERNATIONAL ATOMIC ENERGY AGENCY
}

\author{
ASSISTANCE PROGRAMME
}

$I^{\mathrm{T}}$ was decided at a recent session of the Board of Governors to the International Atomic Energy Agency to supply twenty scientists and legal experts, who would assist and advise in various projects being developed, to ten countries. This decision was taken when the Board of Governors was allocating 60 per cent of the Agency's own technical assistance fund for the current year. The countries to receive such support are Afghanistan, Austria, Brazil, Iran, Iraq, Korea, Philippines, Turkey, Venezuela and Yugoslavia. Of these countries, Austria, Iraq, Philippines and Yugoslavia will receive equipment to a total value of 47,200 dollars in connexion with the work to be undertaken. The allocation was made on the basis of requests for assistance under the 1960 programme received by the end of January, the remainder of the funds being left for requests received by the end of May. In addition, the Agency imple. ments an assistance programme under the United Nations Expanded Programme of Technical Assistance.

\section{Afghanistan}

Progress in the nuclear development field in Afghanistan has been retarded by a lack of trained personnel and training facilities. Since experience in these fields is very limited in Afghanistan, the Government has requested the International Atomic Energy Agency to provide the services of a nuclear physicist to assist in drawing up a programme; he will also train staff and lecture at the Faculty of Science in the University of Kabul, and assist in establishing a nuclear physics laboratory within the University.

\section{Austria}

One biochemist will work at the Austrian Cancer Research Institute in Vienna to advise on the use of radioisotopes in cancer research and on the establishment of a radioisotope laboratory. He will train Austrian scientists in the techniques of determining the distribution of labelled tumour cells in experimental animals. The Agency will also provide some nuclear equipment for this project.

\section{Brazil}

One expert in prospecting for nuclear raw materials will visit Brazil to assist the Government's prospecting programme. $\mathrm{He}$ will also assist in organizing field training of geologists and prospectors. The Brazilian authorities plan to co-ordinate the country's activities in the field of radioactive minerals and prospecting. The Agency will provide the services of a nuclear geologist to assist in this project, and particularly in planning and organizing a large-scale geological programme.

In connexion with creating a division of nuclear metallurgy at the Institute of Atomic Energy in São Paolo, a nuclear metallurgy expert will be sent to Brazil. He will advise on the organization and working plans of metallurgical laboratories, on the training of specialists and on the co-ordination of work with other institutions in Brazil.

Another expert will work at the Institute of Atomic Energy at São Paolo and assist in training chemists in radiochemistry and isotope separation as applied to the production of radioisotopes. He will also be concerned with the organization and preparation of the research programme of the radiochemical laboratories, and assist in the activities of the Research Institute at Belo Horizonte and other research organizations in Brazil.

The Government of Brazil plans to work out legal rules on third-party liability and insurance for nuclear hazards in connexion with its nuclear power programme, and particularly the Mambucaba nuclear power project. A legal expert will be sent to Brazil to advise the authority for the Mambucaba project on these questions.

\section{Iran}

The National Iranian Atomic Energy Commission and the Ministry of Industry are conducting a thorough exploration of Iran's radioactive mineral resources and a survey of the possibilities of mining and producing uranium in the future. Two experts from the International Agency will be attached to this project. One of them will work at the Prospecting Section of the Geological Department of the Ministry of Industry and Mines and advise on organization and methods of radiometric surveys and give further training to the staff. The second expert will work at the Mining Section of the same Department and will assist in installing uranium ore processing equipment and instruct laboratory staff in methods of testing and processing uranium ores as well as in geochemical methods of prospecting for uranium.

\section{Iraq}

Two experts, one in the agricultural and one in medical applications of radioisotopes, will visit Iraq, and some equipment will be supplied.

One expert will work on investigations into soil reclamation, fertility surveys and crop improvement he will also supervise the establishment of an agricultural radioisotope laboratory and direct the research work in the laboratory on soil-plant-water relationships.

The expert in the medical application of radio. isotopes will work at the Radioisotope Department of the Republic Hospital in Baghdad and train new Iraqi staff in the medical uses of radioisotopes, in particular in their diagnostic and therapeutic applications.

\section{Korea}

The Korean authorities have established an Atomic Energy Research Institute near Seoul, where a swimming-pool reactor, Triga Mark II, will be put into operation during 1960. In connexion with the reactor project, the Government of Korea will be 
assisted by an Agency health physicist, who will advise on all health physics matters relating to the project,

\section{Philippines}

A radiochemist will be sent to the Philippines to advise the Atomic Energy Commission on the organization of radioisotope courses and on the radiochemical facilities of the reactor to be built at the projected nuclear research centre near the University of the Philippines.

The International Atomic Energy Agency will also provide some equipment, including counters, ioniza tion chambers, rate-meters and other instruments.

\section{Turkey}

An expert in atomic energy planning will go to Turkey at the request of the Government to advise it on working out a detailed long-range atomic energy programme, on the establishment and operation of the necessary facilities and laboratories to implement this programme and on the setting up of new training and research centres.

A research and training reactor is under construction near Istanbul. To elaborate a detailed and effective research and utilization programme for the reactor the Turkish Atomic Energy Committee has established a committee of scientists and requested the International Atomic Energy Agency to provide the services of an expert on reactor utilization to assist in the activities of the Committee. In addition, the expert will advise on setting up and utilizing a sub-critical assembly in the Faculty of Science at the University of Ankara.

\section{Venezuela}

A legal expert will be sent to Venezuela to advise the Government on legislative and administrative problems relating to its atomic energy programmes. and assist in planning and drafting the required legislation as well as in training Venezuelan staff on legal matters.

\section{Yugoslavia}

An expert in the agricultural applications of isotopes will work at the Yugoslav Institute for the Application of Nuclear Energy in Agriculture, Veterinary Sciences and Forestry in Belgrade. He will assist in equipping the Institute and in the organization and development of a laboratory. To assist the expert in his work and to help in setting up the laboratory the Agency will provide counting and dosimetry equipment.

An expert in the medical uses of atomic energy will be sent to Yugoslavia to initiate elinical research work at the medical radioisotope laboratories in Belgrade, Ljubljana and Zagreb. He will also lecture on the applications of isotopes at a course organized by the Federal Nuclear Energy Commission and advise the Commission on future activities related to the medical applications of radioisotopes.

One biochemist will be attached to the Institute for Biology at Zagreb to help its staff to fight fasciolosis, a cattle disease which is estimated by the Government to cost Yugoslavia 8,000 million dinars annually. He will assist in equipping the radioisotope laboratory of the Institute and train the local staff in the applications of tracers to research. Some nuclear laboratory equipment will also be provided.

\section{THE RESEARCH ASSOCIATION OF BRITISH FLOUR MILLERS}

\section{NEW LABORATORIES}

\begin{abstract}
CONSIDERABLE extensions to the laboratories $\lambda$ of the Ceroals Research Station, provided by the Millers Mutual Association, and which include new analytical and research laboratories, animal unit, workshop, committee, lecture and common rooms and canteen, were opened by Lord Rank on May 4. In his speech, he said that there was no need now to remind any industrialist that to be successful he must have the best scientific advice and stimulus at his elbow. While individual milling companies had their own scientific units, the industry looked to the Research Association for leads on major scientific developments; the Research Association was, in fact, the scientific headquarters of the milling industry. After stressing the importance of nutritional research, he went on to say that in Great Britain we had the best and probably the cheapest bread in the world, and in this achievement the Research Association had played a big part. He could say this with authority, because he was president of the Association during 1930-52.
\end{abstract}

At the luncheon that followed, the president, $\mathrm{Mr}$. L. Hector Read, proposed the health of the guests. Before doing so, he thanked Lord Rank and his colleagues for providing the additions to the laboratories and he also expressed the indebtedness of the Research Association for the great help and encouragement received from the Department of Scientific and Industrial Research during the thirty-seven years since the Association was founded. In welcoming the principal guest, Lord Cohen of Birkenhead. he spoke of him as a leader in his profession, as one who has always been keenly interested in scientific and medical research, and as the outstanding modical statesman of the a.ge. In replying, Lord Cohen pointed out that biology, of which medicine is simply an aspect, had advanced mainly by the application of physics and chemistry to the elucidation of complex biological phenomena. For this reason it was to him of immense significance to see such application being made by the Research Association to the problems of cereals. $\mathrm{He}$ noted, too, investigations involving engineering, bacteriology, mycology, entomology, zoology and geneties. With regard to the latter, "Bread and Breed" was indeed a most appropriate title. The restheties of bread, its palatability and appearance, and other fields of the arts also entered into the work of the Association, and he wondered whether here in these laboratories would be found the appropriate marriage of the two cultures, science and art, of which Sir Charles Snow spoke recently.

The laboratorios were afterwards opened for inspection, and a number of demonstrations were given illustrating the current research programme. These included the structure and chemistry of the 